\title{
Anthropometric Analysis in Mentally Retarded Children of South Kerala
}

\author{
Dr.Romi.S ${ }^{1}$, Dr.Lola Das ${ }^{2}$ \\ ${ }^{\text {I}}$ (Professor \& HOD, Department Of Anatomy, Govt T.D.Medical College, Alappuzha, Kerala, India) \\ ${ }^{2}$ (Professor \&HOD, Department Of Anatomy, Govt. Medicalcollege, Manjery, Kerala, India)
}

\begin{abstract}
Objectives: Mental retardation is a common problem. The present study has been undertaken to find out whether there was any definite anthropometric measurements suggestive or diagnostic of idiopathic mental retardation.

Materials and method: 100 children with idiopathic mental retardation were selected from various Institutions for mentally retarded children. Controls were selected as 120 students from the nearby Government schools having normal intelligence and behaviour. For this study the method of Singh and Bhasin was followed. Recording of measurements, calculation of indices and statistical analysis were done.

Design: Descriptive study

Results:Mentally retarded children shows lower values of height, weight, anteroposterior dimension(APD), biparietal dimension(BPD), cranial height (Cr.Ht), occipitofrontal circumference (OF),Cranial capacity, cranial index and length-height index.

Conclusion: Idiopathic mental retardation has a stronggenetic basis.Lower values of craniometry suggested a slower growth of cranium consequent to the reduced growth of brain.
\end{abstract}

Keywords: biparietal dimension, cephalometry, cranial capacity, cranial index, mental retardation

\section{Introduction}

Anthropometry is the single most portable,universally applicable less expensive and non-invasive technique for assessing the size, proportions and composition of human body.In modern era anthropometric measurements had more practical applications particularly in areas of genetic research and work place ergonomics.Anthropometry helps in identifying differences between mentally retarded males with or without fragile $\mathrm{X}$ syndrome and offers a comprehensive approach for screening males for the fragile $\mathrm{X}$ syndrome ${ }^{[1]}$.Craniometry is a specializedbranch of anthropometry, the quantitative study of head. Mentally disabled children shows higher incidence of malocclusion compared with control children ${ }^{[2]}$.Down syndrome children shows facial disproportion leads to malocclusion ${ }^{[3,4]}$. Brain development in autism follows an abnormal patternso thatthe headcircumference was increased in these children ${ }^{[5]}$.It was estimated that $2 \%$ of Indian population suffer from mental retardation ${ }^{[6]}$

\section{Materials And Methods}

The study was done among 100 children with idiopathic mental retardation from the following institutions for mentally retarded children.

- Government Institution for mentally retarded children at Pangappara, Trivandrum.

- Neurology clinic at S.A.T Hospital, Trivandrum.

- Maryon School at Kanaka Nagar, Trivandrum.

120 school going children who did not exhibit any mental deficiency formed the control group. These children were selected from nearby Government schools of age group 7-15 years of both sexes.

2.1. Inclusion criteria: Children between the age group 7-15 years. Mentally retarded children not affected by Down syndrome.

2.2. Exclusion criteria: Children below 7 years and above 15 years.

For this study the method of Singh and Bhasin ${ }^{[7]}$ was followed. This consists of

- Recording of measurements

- Calculation of Indices

- Statistical analysis. 


\subsection{Measurements}

\subsubsection{Height}

The subject was asked to stand bare foot on the floor with heels, buttocks, back and head touching the wall. The height was measured using an anthropometer and was recorded to one-tenth of a centimetre.

\subsubsection{Weight}

The subject was asked to standbare foot in the centre of the platform of a standardised weighing machine exerting equal pressure on both the feet without any movement.The weight was recorded to one-tenth of a kilogram.

2.3.3. Head circumference (occipitofrontal circumference/OF)

Using a flexible centimetre tape circumference was noted at the level of external occipital protuberance and glabella. Glabella is the midpoint of the part of frontal bone above the nasal root between the supraorbital ridges.

\section{Figure 1}

2.3.4. Anteroposterior Dimension (APD)

The maximum length of the cranial diameter from glabella to the external occipital protuberance measured using a spreading calliper (Fig 1).

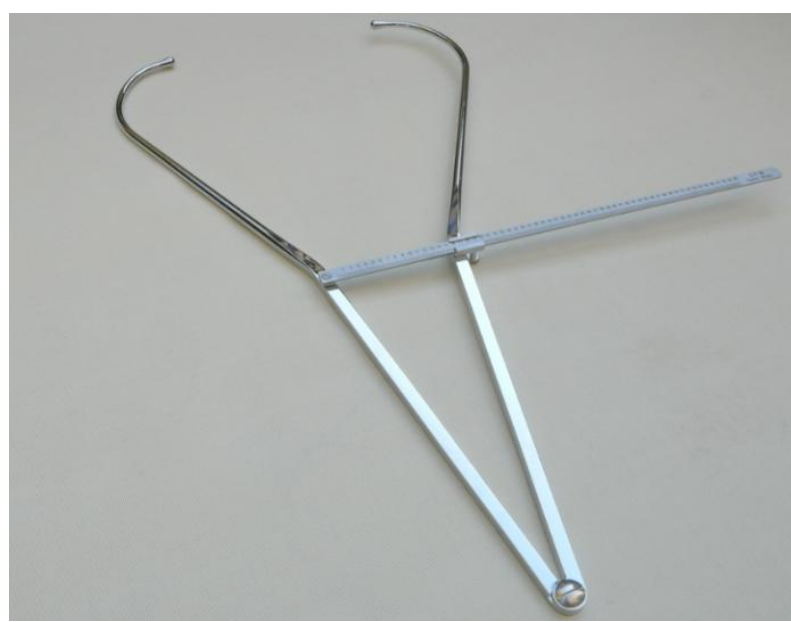

Figure 1 : Spreading Callipers

\subsubsection{Biparietal Dimension( BPD )}

The greatest horizontal and transverse diameter measured on the headby the spreading calliper (Fig 1) above the supramastoid region

2.3.6. Cranial height ( $\mathrm{Cr}$. $\mathrm{Ht}$ )

The distance between the vertex superiorly and the superior border of auditory opening inferiorly measured by spreading calliper(Fig 1)

2.3.7. Facial height (F. Ht)

The distance between glabella and symphysis menti was measured using a sliding calliper (Fig.2)

2.3.8. Bizygomatic breadth ( BZ)

The distance between the midpoints of two zygomatic arches was measured using the spreading calliper (Fig 1).

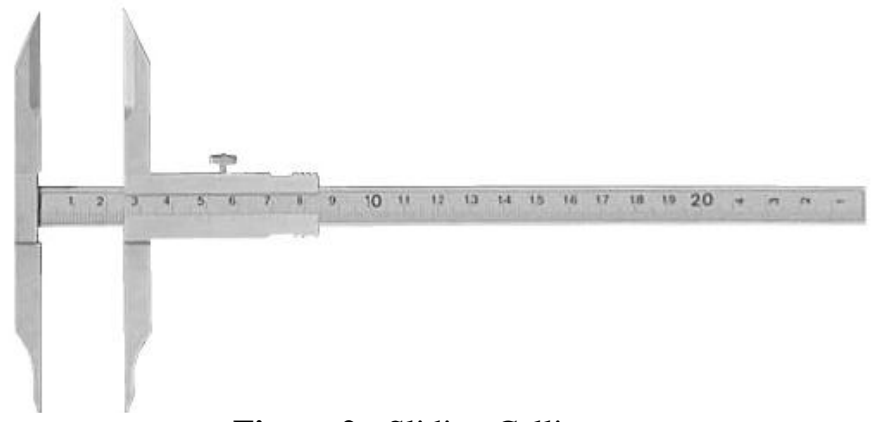

Figure 2 : Sliding Callipers 
2.4. Indices

2.4.1. Calculation of Indices

2.4.1.1. Cranial capacity

This can be calculated as per the formula given below ${ }^{[8]}$

For male cranial capacity $=0.000337(\mathrm{~L}-11)(\mathrm{B}-11)(\mathrm{H}-11)+406.01 \mathrm{cc}$.

For Female $=0.000400(\mathrm{~L}-11)(\mathrm{B}-11)(\mathrm{H}-11)+206.60 \mathrm{cc}$.

$\mathrm{L}$-Length of cranium

B - Breadth of cranium

$\mathrm{H}$ - Height of cranium

2.4.1.2. Cranial index

(Biparietal distance/cranial height) x100

2.4.1.3. Cranial length height index

Cranial height/ cranial length) $\mathrm{x} 100$.

2.4.1.4. Transverse craniofacial index

(Bizygomatic distance/Biparietal distance) x 100

2.4.1.5. Facial index

(Bizygomatic distance/ Facial height) x 100.

\subsection{Analysis}

2.5.1. Statistical Analysis

The collected data was analysed statistically under the guidance of a Biostatistician. Mean and standard deviation of control and mentally retarded children were calculated.

\section{Results}

Table 1: Mean Height (in Centimetres) of control and mentally retarded children.

\begin{tabular}{|l|l|c|}
\hline & Male & Female \\
\hline C & 132.30 & 132.40 \\
\hline MR & 130 & 129.33 \\
\hline
\end{tabular}

C- Control children

MR- Mentally retarded children

Mean values of height was decreased in mentally retarded children of both sexes.

Table 2: Mean weights (in Kilo grams) of controls and mentally retarded children.

\begin{tabular}{|l|l|l|}
\hline & Male & Female \\
\hline $\mathrm{C}$ & 30.15 & 29.15 \\
\hline MR & 25.42 & 28.75 \\
\hline
\end{tabular}

Table 2 shows that mean weight of mentally retarded children were definitely low.

Table 3: Cranial dimensions (in Centimetres) of male and female control and mentally retarded children

\begin{tabular}{|l|l|l|l|l|l|}
\hline Parameter & $\begin{array}{l}\text { Study } \\
\text { group }\end{array}$ & \multicolumn{2}{|c|}{ Male } & \multicolumn{2}{c|}{ Female } \\
\hline & & & SD \pm & & SD \pm \\
\hline Anteroposterior Dimension(APD) & $\mathrm{C}$ & 16.5 & 0.51 & 16.3 & 0.57 \\
\cline { 2 - 7 } & MR & 15.9 & 1.12 & 16.2 & 1.40 \\
\hline \multirow{2}{*}{$\begin{array}{l}\text { Biparietal } \\
\text { Dimension(BPD) }\end{array}$} & $\mathrm{C}$ & 13.0 & 0.46 & 12.4 & 0.60 \\
\cline { 2 - 7 } Cranial Height (Cr. Ht) & MR & 12.3 & 1.24 & 12.2 & 1.49 \\
\hline & $\mathrm{C}$ & 11.9 & 0.31 & 11.6 & 0.50 \\
\cline { 2 - 7 } & MR & 11.1 & 1.21 & 11.2 & 0.92 \\
\hline $\begin{array}{l}\text { Occipitofrontal } \\
\text { Circumference(OF) }\end{array}$ & $\mathrm{C}$ & 51.7 & 1.42 & 52 & 1.17 \\
\cline { 2 - 6 } & MR & 49.8 & 2.99 & 49.9 & 3.03 \\
\hline
\end{tabular}

In Table 3; APD,BPD and Cr. Ht shows statistically significant lower values in male mentally retarded children. But $\mathrm{OF}(\mathrm{P}<0.01)$ is lower in both sexes.

Table 4: Cranial indices of control and mentally retarded children of both sexes

\begin{tabular}{|l|l|l|l|l|}
\hline \multirow{2}{*}{ Parameter } & Male & Female \\
\cline { 2 - 5 } & C & MR & C & MR \\
\hline Cranial index & 78.05 & 75.47 & 77.00 & 74.91 \\
\hline CranialCapacity(in cc) & 406.012 & 406.010 & 206.603 & 206.603 \\
\hline Length-heightIndex & 72.25 & 71.47 & 70.90 & 69.83 \\
\hline Transverse cranio facial index & 91.20 & 102.10 & 91.20 & 98.91 \\
\hline Facial index & 94.55 & 99.52 & 103.60 & 100.25 \\
\hline
\end{tabular}


Table 4 shows that cranial index is not statistically significant.Cranial capacity is significant in males $(\mathrm{P}<0.01)$. Transverse cranio facial index is highly significant in males $(\mathrm{P}<0.001)$ and significant in females. Length height index and facial index were not significant in both sexes.

\section{Discussion}

Mental subnormality is one of those disorders where the understanding or the therapy is a matter of disillusionment. Of the various endogenous and exogenous influences acting independently or in concert with each other, heredity has been considered fairly significant in the causation of intellectual deficiency. The correlation between mental retardation and anthropometry, particularly the cranial measurements were studied ${ }^{[9}$, ${ }^{10]}$. The study of growth and development of body as a whole and skull in particular is important in case of mental retardation. The growth of face is mainly related to genetic pattern, the general health and environment of the individual. Cranium enlarges in all its dimensions and attains $90 \%$ of its full growth by about 6-7 years. The prevalence of malnutrition is high among mentally retarded children. The lower values in height and weight in the present study clearly indicates the physical and mental retardation are directly interlinked ${ }^{[1]}$. In this study head measurements such as anteroposterior dimension, biparietal dimension, cranial height and occipitofrontal distance were significantly lower in all the mentally retarded children irrespective of age and sex. A similar finding was suggested by many other researchersand Krogman ${ }^{[12]}$. Since cranial capacity is an indirect approach to evaluate the size of the brain, its decrease in the mentally retarded children support the view that brain size is smaller in them. The significantly lower values in our studies were supported by previous workers ${ }^{[13,14]}$. The significantly lower values for the cranial capacity in this study corroborates the above reports. The decreased values of cranial index, length-height index and facial index suggest a slower growth of the cranium consequent to the reduced growth of the brain. Arole ${ }^{[15]}$ has reported similar views in deaf and dumb children. Atypical physical features such as microcrania were noted to be associated with mental retardation in the above study. The higher values of transverse craniofacial index might be the result of comparative rapid and compensatory overgrowth of the air sinuses in the mentally retarded children. In general the present study very strongly supports the suggestion that the gradual falling away from normal physical growth channels may be due to some brain disorders leading to mental retardation. Strength of this study were the following facts: A relatively rather unexplored area of research could be used. Simple, less expensive, need minimal training and the most practical tools were used to study the cases. Readings are reproducible; objectiveshave high specificity and sensitivity. Besides, this study has proved that idiopathic mental retardation has a strong genetic basis.

Limitations of this study were inter-observer errors in measurements and problems with reference standards i.e. local verses international standards.

\section{Conclusion}

Anthropometric study showed that cranial capacity was lower in mentally retarded male children. The head circumference, a measurement very widely used by paediatricians in doubtful cases of mental deficiency was found to be lower in this study. Similarly the cranial index was also lower in these children. These measurements can be used as a diagnostic tool for mental subnormality among low achievers in schools. This will help in creating awareness in the parents of such children. Moreover early diagnosis will help in framing the rehabilitation programs. The suggestive cases could be subjected to mere advanced, expensive and sophisticated methods such as cytogenetic analysis and polymerase chain reaction.

\section{References}

[1]. Butter MG, Pratesi R,Watson MS, Beg WR,Singh DN Anthropometric and craniofacial patterns in mentally retarded males with emphasison the fragile X syndrome.Clin Genet.1993 Sept; 44(3):129- 138[2] Thapar R, Angadi P.V, Hallikerimath S, Kale AD (2012). Sex assessment using odontometry and cranial anthropometry: evaluation in an Indian sample: Forensic Sci Med Pathol $8 ; 94-100$

[2]. Sivakumar K, Chandu G, Shaffiulla M(2010) Severity of Malocclusion and Orthodontic Treatment Needs among 12 to 15 year old School Children of Davangere District Karnataka.India Eur.J.Dent 4; 298-307

[3]. Shivakumar KM, Chandu GN, Subba Reddy VV, Shaffiulla MD(2009) Prevalance of malocclusion and orthodontic treatment needs among middle and high school children of Davangere District,Karnataka, India by using dental Aesthetic Index. J Indian Soc Pedod Prev Dent 27: 211-218

[4]. Aylward E.H, Minshew N.J (Effects of age on brain volume and head circumference in Neurology 2002) 59:2 175-183

[5]. OP Ghai, Central nervous system(Essential Paediatrics6 ${ }^{\text {th }}$ edition, CBS Publishers New Delhi, 2004) P500-545.

[6]. Singh I.P. and Bhasin, M.K.1968. A laboratory manual on biological Anthropology(Antropometry section- 1 Kamala- Raj enterprises Delhi)

[7]. Hrdlicka A,1919, Anthropometry.Am.J.Phys.Anthrop, 21,287 (cited by Singh and Bhasin 1968).[9] Scottand Dixon 1959. In Anatomy for students of Dentistry PP.320-345 London. E\&S Livingstone Ltd.

[8]. Kannappan J.G, Shourie K.L and Shaikh H.S 1967.The craniagrowth. An anthropometric study in Indians.J.Anat.Soc.India Vol.XVI No.3

[9]. Hass.J.D,Hunt. E.E. and BuskirkE.R 1973, skeletal development of non-institutionalised children with low Intelligence Quotients.Am.J.Phys.Anthrop,35:455-466. 
[10]. Krogman,W.M.1930.The problem of growth changes in face and skull viewed from a comparative study of Anthropoids and man. Dental Cosmos.72:

[11]. Hoadley, M.F 1929. On measurement of diameters of skulls in relation to capacity, Biometrika, 21, 5-12

[12]. Shukla A.P 1980. A study of cranial index of Indian skulls. J.Anat.Soc.India.Vol.29.No.3

[13]. Arole, V,Kate.B.R. and Athanikar. K.A 1981. J.Anat.Soc. India vol.30, No.3 